\title{
Bacillus ruris sp. nov., from dairy farms
}

\author{
Correspondence \\ Marc Heyndrickx \\ M.Heyndrickx@clo.fgov.be
}

\author{
Marc Heyndrickx, ${ }^{1}$ Patsy Scheldeman, ${ }^{1}$ Gillian Forsyth, ${ }^{2}$ Liesbeth Lebbe, ${ }^{3}$ \\ Marina Rodríguez-Díaz, ${ }^{2}$ Niall A. Logan ${ }^{2}$ and Paul De Vos ${ }^{3}$
${ }^{1}$ Department of Animal Product Quality, Centre for Agricultural Research-Ghent, Brusselsesteenweg 370, B-9090 Melle, Belgium
${ }^{2}$ Department of Biological and Biomedical Sciences, Glasgow Caledonian University, Cowcaddens Road, Glasgow G4 OBA, UK \\ ${ }^{3}$ Vakgroep BFM WE10V, Laboratorium voor Microbiologie, Universiteit Gent, \\ K. L. Ledeganckstraat 35, B-9000 Gent, Belgium
}

\begin{abstract}
Four novel ellipsoidal spore-forming Bacillus isolates with swollen sporangia, isolated from raw milk and feed concentrate, showed a high level of similarity in SDS-PAGE, fatty acid methyl esters and routine phenotypic tests. However, 16S rRNA gene sequence comparisons showed that this taxon was different from other related Bacillus species, and only a low level of DNA relatedness was found with the closest phylogenetic and phenotypic relative, Bacillus galactosidilyticus. This taxon could be differentiated from $B$. galactosidilyticus on the basis of morphological differences, stronger acid reactions with a wide range of substrates after $48 \mathrm{~h}$ incubation, and qualitative and quantitative differences in fatty acid content. On the basis of these data, a novel species, Bacillus ruris sp. nov., is proposed, with LMG $22866^{\top}$ (=DSM $17057^{\top}$ ) as the type strain.
\end{abstract}

In the study of some milk and dairy-farm isolates that led to the proposal of the novel species Bacillus galactosidilyticus, a strain $\left(\mathrm{R}-6760^{\mathrm{T}}\right)$ was encountered which showed a high degree of phylogenetic relatedness $(98 \cdot 3 \% 16 \mathrm{~S}$ rRNA gene sequence similarity) with respect to the type strain of this species (Heyndrickx et al., 2004). However, on the basis of a low DNA relatedness value with respect to $B$. galactosidilyticus, it was concluded that this strain represented the core of another novel Bacillus species. In the course of a polyphasic taxonomic characterization of aerobic, endospore-forming isolates from dairy farms, three more isolates were found that showed a close relationship to each other and to this strain. As a result, a novel species, Bacillus ruris sp. nov., is proposed.

The previously reported (Heyndrickx et al., 2004) rawmilk strain R-6760 ${ }^{\mathrm{T}}\left(=\operatorname{Logan} \mathrm{B} 3037^{\mathrm{T}}=\mathrm{MB} 1669^{\mathrm{T}}\right)$ and the novel feed-concentrate strain LMG 22867 (=R$7400=$ Logan B3038) were deposited in the BCCM/LMG (Belgian Co-ordinated Collections of Micro-organisms/

Published online ahead of print on 9 September 2005 as DOI 10.1099/ijs.0.63812-0.

The GenBank/EMBL/DDBJ accession number for the 16S rRNA gene sequence of strain LMG $22866^{\top}$ is AJ535639.

A UPGMA clustering of normalized SDS-PAGE patterns of whole-cell proteins of isolates belonging to Bacillus ruris sp. nov. and the Bacillus galactosidilyticus type strain and a table showing the cellular fatty acid methyl ester profiles of strains of $B$. ruris sp. nov. and of $B$. galactosidilyticus are available as supplementary material in IJSEM Online.
Laboratory of Microbiology Ghent) public collection (Ghent University, Belgium) as LMG $22866^{\mathrm{T}}$ and LMG 22867, respectively. Two other novel strains, R-7794 (=Logan B3039) and R-8025 (=Logan B3040), were each isolated from feed concentrate. All four strains were isolated from a different dairy farm, after heat treatment $\left(30 \mathrm{~min}\right.$ at $100^{\circ} \mathrm{C}$ ) for selection of potentially highly heatresistant spores such as those of Bacillus sporothermodurans, by means of plating on brain-heart infusion (Oxoid) supplemented with bacteriological agar no. $1\left(15 \mathrm{~g} \mathrm{l}^{-1}\right)$ (Oxoid) and filter-sterilized vitamin $\mathrm{B}_{12}\left(1 \mathrm{mg} \mathrm{l}^{-1}\right)$ and incubation at $37^{\circ} \mathrm{C}$ for $48 \mathrm{~h}$. Genomic DNA of strain LMG $22866^{\mathrm{T}}$ was purified as described by Logan et al. (2000), with the modifications described by Heyndrickx et al. (2004). The $\mathrm{G}+\mathrm{C}$ content of the DNA was determined by using HPLC as described by Logan et al. (2000). Cells of strains LMG $22866^{\mathrm{T}}$, LMG 22867, R-7794 and R-8025 were obtained as described by Heyndrickx et al. (1998) and subjected to SDS-PAGE analysis of whole-cell proteins according to the method of Pot et al. (1994). The SDS-PAGE data were collected and interpreted as described by Vauterin \& Vauterin (1992). For GC analysis of the fatty acid methyl esters, cells of the strains were grown and analysed as described by Heyndrickx et al. (1998) and Vauterin et al. (1991). The strains were characterized phenotypically by the methods of Logan \& Berkeley (1984); further characteristics were determined and the data were numerically analysed as described by Logan et al. (2000).

In comparisons of 16S rRNA gene sequences with entries in the EMBL database, the closest ungapped FASTA matches 
with a species with a validly published name achieved for strain LMG $22866^{\mathrm{T}}$ (1423 bp; EMBL accession no. AJ535639) was $98 \cdot 3 \%$ with B. galactosidilyticus (EMBL accession no. AJ535638) and $96.6 \%$ with Bacillus lentus (EMBL accession no. AB021189). On the other hand, a 16S rRNA gene sequence similarity of $99 \cdot 9 \%$ was found with entries of unidentified low- $\mathrm{G}+\mathrm{C}$ Gram-positive isolates from compost deposited in GenBank/EMBL (accession nos $\mathrm{AB} 116129, \mathrm{AB} 116128$ and $\mathrm{AB} 116144)$. In a phylogenetic cluster analysis using neighbour-joining (Fig. 1), it was shown that strain LMG $22866^{\mathrm{T}}$ clustered close to the type strain of B. galactosidilyticus in the radius of the genus Bacillus and with B. lentus and related species as the closest phylogenetic relatives.

The four strains LMG $22866^{\mathrm{T}}$, LMG 22867, R-7794 and R8025 showed very similar patterns in SDS-PAGE analyses, and clustered at a similarity level of $91 \%$. Nevertheless, some variation in the SDS-PAGE patterns was visible. These data together with data for the strains from different farms indicate that the organisms were not duplicate isolates. The B. galactosidilyticus type strain, LMG $17892^{\mathrm{T}}$, showed a similarity of $83 \%$ to this group of strains (a UPGMA clustering of normalized SDS-PAGE patterns is available as a supplementary figure in IJSEM Online).

The fatty acid methyl ester data revealed a dominance of

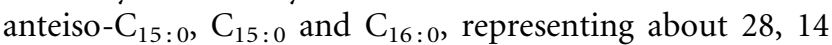
and $33 \%$, respectively, of the total fatty acid content in this group of strains (see the supplementary table available in IJSEM Online). Some qualitative and quantitative differences in fatty acid content could be observed between the group of four strains described above and the phylogenetically closest relative, B. galactosidilyticus: the group of four strains contained small amounts of $C_{17: 0}$, but no $C_{13: 0}$ or $\mathrm{C}_{16: 1} \omega 11 c$ (B. galactosidilyticus contained trace amounts of the last two fatty acids but lacked the former fatty acid) and they contained more $\mathrm{C}_{15: 0}$ and less iso- $\mathrm{C}_{15: 0}$ in comparison with B. galactosidilyticus.

In the API $50 \mathrm{CHB}$ tests (bioMérieux; data not shown) the four strains LMG $22866^{\mathrm{T}}$, LMG 22867, R-7794 and R-8025 gave strong acid reactions with a wide range of substrates after $48 \mathrm{~h}$ incubation. In general, the four strains presented consistent phenotypic profiles, with similar results in API $20 \mathrm{E}$ tests (bioMérieux) and in morphological observations. In a numerical analysis of the API tests, the four strains formed a distinct cluster at $87 \cdot 5 \% S_{\mathrm{G}}$, which then joined with a larger cluster containing strains of B. galactosidilyticus, Bacillus firmus and members of the Bacillus cereus group at only $72 \cdot 5 \% S_{\mathrm{G}}$. Phenotypic characteristics that distinguish the four above-mentioned strains from some phenotypically similar and phylogenetically related Bacillus species are shown in Table 1.

It had been reported previously that strain LMG $22866^{\mathrm{T}}$ $\left(=\mathrm{R}-6760^{\mathrm{T}}\right)$ showed only a low level of DNA relatedness $(32.5 \%)$ with the type strain of B. galactosidilyticus, its closest relative in phylogenetic terms (Heyndrickx et al., 2004). The genetic and phenotypic data presented above show that strains LMG $22866^{\mathrm{T}}$, LMG 22867, R-7794 and R8025 belong to a novel Bacillus species, for which we propose the name Bacillus ruris sp. nov.

\section{Description of Bacillus ruris sp. nov.}

Bacillus ruris (ru'ris. L. neut. n. rus the country, the farm; L. gen. n. ruris from the country, the farm).

Cells are rods and coccoid rods $0 \cdot 5-0 \cdot 8 \mu \mathrm{m}$ in diameter and $1 \cdot 0-2 \cdot 0 \mu \mathrm{m}$ in length, motile, Gram-positive, occurring singly and in pairs as well as in chains of three to four cells. They bear ellipsoidal endospores that lie in subterminal, paracentral and central positions within swollen sporangia (Fig. 2). After 2 days on trypticase soy agar, colonies are smooth, flat and butyrous, approximately $1 \mathrm{~mm}$ in diameter, their edges are usually irregular, and they are creamy or off-white in colour, with opaque centres. The type strain, LMG $22866^{\mathrm{T}}$, is facultatively anaerobic and catalasepositive. Growth of the type strain occurs at 30 and $40^{\circ} \mathrm{C}$ but not at $50{ }^{\circ} \mathrm{C}$, and between pH 6 and 11 . Casein is not hydrolysed. In API 20E tests, the ONPG reaction is positive, and nitrate is reduced to nitrite; arginine dihydrolase, lysine decarboxylase and ornithine decarboxylase, citrate utilization,

\section{$5 \%$}

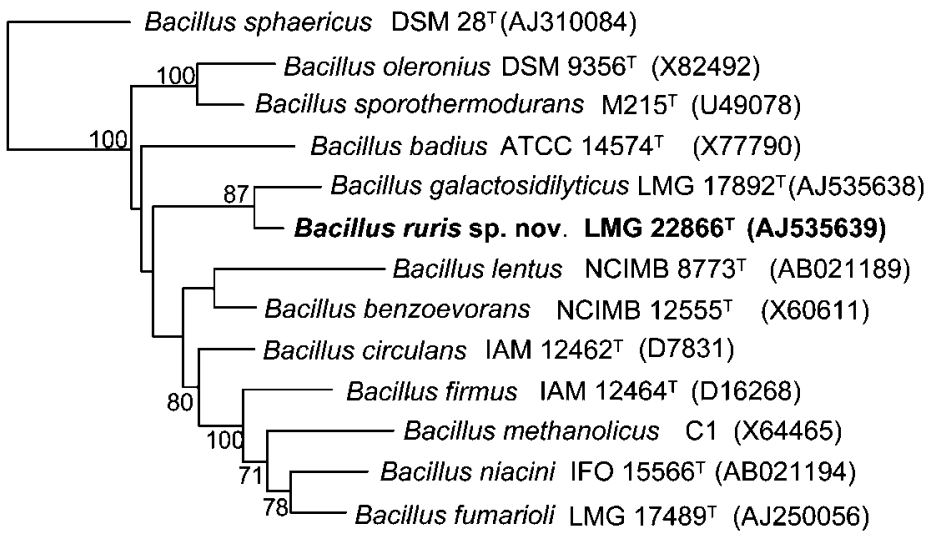

Fig. 1. Neighbour-joining clustering (showing bootstrap values above $70 \%$ ) of $16 \mathrm{~S}$ rRNA gene sequences (rooted with Bacillus sphaericus as the reference), based on a selection of $16 \mathrm{~S}$ rRNA gene sequences of the nearest neighbours of $B$. ruris LMG $22866^{\top}$, taken from GenBank/EMBL (accession nos are given in parentheses). Bar, percentage of nucleotide substitutions per nucleotide position. 
Table 1. Characteristics useful for distinguishing between $B$. ruris sp. nov. and some phenotypically similar and phylogenetically related Bacillus species

With the exception of microscopic observations, anaerobic growth and casein hydrolysis, all characteristics were determined using tests in the API 20E and 50 CHB systems. Symbols: +, more than $85 \%$ of the strains positive; $(+)$, $75-84 \%$ of the strains positive; V, variable (26-74\% of the strains positive); (-), 16-25\% of the strains positive;,$- 0-15 \%$ of the strains positive; $+/ \mathrm{W}$, positive or weakly positive; $\mathrm{W}$, weak positive reaction; $\mathrm{v} / \mathrm{W}$, variable, and weak when positive.

\begin{tabular}{|c|c|c|c|c|c|c|}
\hline Characteristic & B. ruris & B. galactosidilyticus & B. firmus & B. cereus & B. licheniformis & B. subtilis \\
\hline Swollen sporangia ${ }^{*}$ & + & + & - & - & - & - \\
\hline Anaerobic growth & + & + & + & + & + & - \\
\hline Gelatin hydrolysis & - & - & + & + & + & + \\
\hline Casein hydrolysis & - & $\mathrm{W}$ & + & + & + & + \\
\hline Aesculin hydrolysis & + & + & + & + & + & + \\
\hline$N$-Acetylglucosamine & + & $+/ \mathrm{w}$ & $\mathrm{V} / \mathrm{W}$ & + & + & $(-)$ \\
\hline L-Arabinose & + & $\mathrm{V}$ & - & - & + & + \\
\hline Amygdalin & - & $\mathrm{v} / \mathrm{W}$ & - & - & + & + \\
\hline$\beta$-Gentiobiose & - & $\mathrm{v} / \mathrm{w}$ & - & - & + & + \\
\hline Glycerol & - & - & + & + & + & + \\
\hline Starch & + & $\mathrm{V} / \mathrm{W}$ & + & + & + & + \\
\hline Sucrose & + & $\mathrm{v} / \mathrm{w}$ & + & $\mathrm{V}$ & + & + \\
\hline D-Tagatose & - & - & - & - & + & - \\
\hline D-Xylose & + & $\mathrm{v} / \mathrm{W}$ & - & - & + & + \\
\hline
\end{tabular}

*The sporangial swelling shown by B. galactosidilyticus is only slight.

hydrogen sulphide production, urease production, the VogesProskauer reaction, indole production and gelatin hydrolysis are all negative. Hydrolysis of aesculin is positive. In

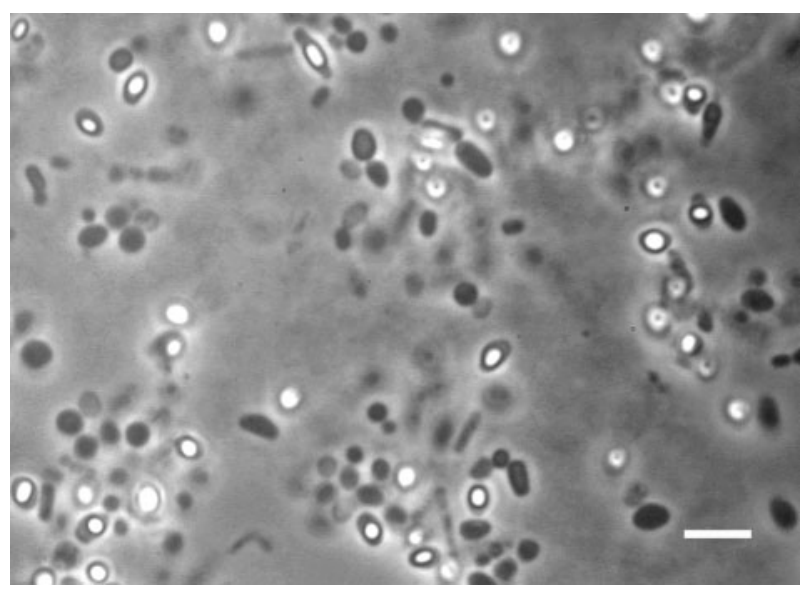

Fig. 2. Photomicrograph of sporangia and vegetative cells of B. ruris LMG $22866^{\top}$ viewed by phase-contrast microscopy. Vegetative cells are rods and coccoid rods, and ellipsoidal spores lie centrally, paracentrally and subterminally within swollen sporangia. Bar, $2 \mu \mathrm{m}$. the API 50 CHB gallery, acid is produced without gas from $\mathrm{N}$-acetylglucosamine, L-arabinose, D-glucose, D-fructose, lactose, D-mannose, D-melezitose, D-melibiose, ribose, starch, sucrose, D-trehalose and D-xylose. Acid production from the following carbohydrates is variable: D-cellobiose, galactose, glycogen, inulin, maltose, mannitol, methyl D-glucoside, Draffinose and salicin. Acid is not produced from adonitol, amygdalin, D-arabinose, D-arabitol, L-arabitol, arbutin, dulcitol, erythritol, D-fucose, L-fucose, $\beta$-gentiobiose, gluconate, 2 keto-D-gluconate, 5-keto-D-gluconate, glycerol, myo-inositol, D-lyxose, methyl D-mannoside, methyl xyloside, rhamnose, sorbitol, L-sorbose, D-tagatose, D-turanose, xylitol or L-xylose. The major cellular fatty acids (mean percentage \pm standard deviation of total fatty acids) are: $14: 0(6 \cdot 24 \pm 3 \cdot 67 \%)$, iso$15: 0(7 \cdot 43 \pm 1 \cdot 15 \%)$, anteiso-15:0 (27.59 $\pm 6 \cdot 80 \%), 15: 0$ $(14 \cdot 14 \pm 0 \cdot 47 \%)$ and $16: 0(32 \cdot 79 \pm 7 \cdot 72 \%)$. The following fatty acids are present in smaller amounts (mean percentage \pm standard deviation of total fatty acids): iso-14:0 (2.24 \pm $0 \cdot 68 \%)$, iso-16:0 $(2 \cdot 82 \pm 0 \cdot 44 \%)$, anteiso-17:0 $(3 \cdot 49 \pm$ $2 \cdot 22 \%)$ and $17: 0(1 \cdot 79 \pm 0 \cdot 50 \%)$. Small amounts of iso$17: 0$ and $18: 0$ fatty acids may also be present in some strains. The DNA G $+\mathrm{C}$ content of the type strain is $39 \cdot 2 \mathrm{~mol} \%$.

The type strain is LMG $22866^{\mathrm{T}}\left(=\mathrm{DSM} 17057^{\mathrm{T}}=\mathrm{Logan}\right.$ $\left.\mathrm{B} 3037^{\mathrm{T}}=\mathrm{MB} 1669^{\mathrm{T}}\right)$. With regard to the variable 
characteristics listed above, the type strain is positive for the production of acid without gas from D-cellobiose, galactose, glycogen, inulin (weak reaction), maltose, mannitol (weak reaction), methyl D-glucoside, D-raffinose and salicin (weak reaction).

\section{Acknowledgements}

We are very grateful to Elly Engels for excellent technical assistance. We are most grateful to bioMérieux Inc. for providing API materials and for supporting G. F. and M. R.-D.; P.D. V. is indebted to the Fund for Scientific Research - Flanders for personnel and for research grant G.0156.02.

\section{References}

Heyndrickx, M., Lebbe, L., Kersters, K., De Vos, P., Forsyth, G. \& Logan, N. A. (1998). Virgibacillus: a new genus to accommodate Bacillus pantothenticus (Proom and Knight 1950). Emended description of Virgibacillus pantothenticus. Int J Syst Bacteriol 48, 99-106.
Heyndrickx, M., Logan, N. A., Lebbe, L., Rodriguez-Diaz, M., Forsyth, G., Goris, J., Scheldeman, P. \& De Vos, P. (2004). Bacillus galactosidilyticus sp. nov., an alkali-tolerant, $\beta$-galactosidaseproducer. Int J Syst Evol Microbiol 54, 617-621.

Logan, N. A. \& Berkeley, R. C. W. (1984). Identification of Bacillus strains using the API system. J Gen Microbiol 130, 1871-1882.

Logan, N. A., Lebbe, L., Hoste, B., Goris, J., Forsyth, G., Heyndrickx, M. \& De Vos, P. (2000). Aerobic endospore-forming bacteria from geothermal environments in northern Victoria Land, Antarctica, and Candlemas Island, South Sandwich archipelago, with the proposal of Bacillus fumarioli sp. nov. Int J Syst Evol Microbiol 50, 1741-1753.

Pot, B., Vandamme, P. \& Kersters, K. (1994). Analysis of electrophoretic whole organism protein fingerprints. In Chemical Methods in Prokaryotic Systematics, pp. 493-521. Edited by M. Goodfellow \& A. G. O’Donnell. Chichester: Wiley.

Vauterin, L. \& Vauterin, P. (1992). Computer aided objective comparison of electrophoretic patterns for grouping and identification of microorganisms. Eur Microbiol 1, 37-41.

Vauterin, L., Yang, P., Hoste, B., Vancanneyt, M., Civerolo, E. L., Swings, J. \& Kersters, K. (1991). Differentiation of Xanthomonas campestris pv. citri strains by sodium dodecyl sulfate-polyacrylamide gel electrophoresis of proteins, fatty acid analysis, and DNA-DNA hybridization. Int J Syst Bacteriol 41, 535-542. 